\title{
Expression and characterization of recombinant VP19c protein and N-terminal from duck enteritis virus
}

\author{
Jun Xiang ${ }^{1 \dagger}$, Shunchuan Zhang ${ }^{1 \dagger}$, Anchun Cheng ${ }^{1,2,3^{*}}$, Mingshu Wang ${ }^{1,2^{*}}$, Hua Chang ${ }^{1}$, Chanjuan Shen ${ }^{1}$,
} Dekang Zhu ${ }^{1,2}$, Renyong Jia ${ }^{2}$, Qihui Luo ${ }^{2}$, Zhengli Chen², Xiaoyue Chen ${ }^{1,2,3}$

\begin{abstract}
Background: Previous studies have indicated that the VP19c protein and its homology play similar roles in capsid assembly of all Alphaherpesvirus subfamily. However, there is no report on the VP19c protein of duck enteritis virus (DEV). In this study, we expressed the DEV VP19c protein and presented its antigenic properties. Moreover, we developed polyclonal antibody against the VP19c protein and characterized it.

Methods: A recombinant VP19c (rVP19c) and N-terminal were expressed in Escherichia coli (E.coli) and purified by $\mathrm{Ni2+-affinity} \mathrm{chromatography.} \mathrm{The} \mathrm{antigenic} \mathrm{properties} \mathrm{of} \mathrm{the} \mathrm{recombinant} \mathrm{protein} \mathrm{were} \mathrm{determined} \mathrm{by} \mathrm{Western}$ blot and indirect enzyme-linked immunosorbent assay (ELISA). Furthermore, the polyclonal antibodies against the purified recombinant proteins were produced and the titer of polyclonal antibody was determined by ELISA analysis. Finally, the antibody was used to recognize the VP19c in the cells infected with DEV in the immunofluorescence assay.
\end{abstract}

Results: The N-terminally His-tagged rVP19c and rVP19c(N) were produced as inclusion bodies in E. coli strain BL21 (DE3) with molecular weight of about 66 and $46 \mathrm{kDa}$. Then the proteins were purified to reach the level of homogeneity. Western blot and ELISA analysis that the rVP19c seems to be structurally and antigenically very similar to native VP19c and the N-terminus of VP19c may contain most antigenic linear-epitopes. Furthermore, ELISA analysis demonstrated that the titer of polyclonal antibody was approximately 1:12800, and in the immunofluorescence assay, the antibody was able to recognize the VP19c in the cells infected with DEV.

Conclusions: To our knowledge, this was the first report on basic properties of DEV VP19c protein. In the present study, we obtained a high-level expression of the recombinant VP19c protein as well as high titers of rabbit polyclonal antibody against to VP19c protein. The anti-rVP19c serum was able to detect the VP19c protein in DEV infected cells and the VP19c protein targeted to the nucleus as distinct punctate speckles. This specific polyclonal antibody provides a good tool for further studying structural and functional characterization of DEV VP19c.

\section{Background}

Duck viral enteritis (DVE) is an acute, contagious, and lethal disease of waterfowl of the family Anatidae worldwide [1]. The causative agent, duck enteritis virus (DEV), is a member of the family Herpesviridae, in which herpes simplex virus type 1 (HSV-1) is studied most completely. While research on molecular

\footnotetext{
* Correspondence: chenganchun@vip.163.com; mshwang@163.com

+ Contributed equally

'Avian Diseases Research Center, College of Veterinary Medicine of Sichuan Agricultural University,Ya'an, Sichuan, PR China

Full list of author information is available at the end of the article
}

epidemiology of DEV has advanced over the years [2], relatively little is known concerning the structural, functional and immunogenic role of the structural proteins. The DEV virion is enveloped and the genome consists of double-stranded DNA segments packaged in an icosahedral capsid of several structural proteins [3]. The genetic information of viruses is enclosed in a capsid shell, a protein coat whose function is to protect the nucleic acid and to aid in the infectious process. In the HSV-1, capsid is an icosahedral shell, three of whose primary structural components are a major capsid

\section{Biomed Central}

(c) 2011 Xiang et al; licensee BioMed Central Ltd. This is an Open Access article distributed under the terms of the Creative Commons Attribution License (http://creativecommons.org/licenses/by/2.0), which permits unrestricted use, distribution, and reproduction in any medium, provided the original work is properly cited. 
protein (VP5; coded by the UL19 gene) and two minor capsid proteins, VP19c (UL38 gene) and VP23 (UL18 gene). VP19c and VP23 make up the triplex, which plays an essential role in capsid assembly and architecture [4]. Cell localization studies have also demonstrated the requirement of VP19c for the nuclear localization of VP23 [5]. Interestingly, the HSV-1 UL38 is regulated with late kinetics [6], whereas the bovine herpesvirus type $1(\mathrm{BHV}-1)$ and pseudorabies virus (PRV) UL38 transcript belong to the early kinetic class $[7,8]$. Most of the information of DEV UL38 gene currently is from bioinformatic approaches. Lacking an antibody against DEV VP19c, studies on biofunctions related to it are limited.

Computational predictions of the VP19c amino acid sequence revealed that epitopes were more abundant on the N-terminal half of the VP19c protein than the Cterminal half of it [9]. Hence, in the present study, partial and full-length coding open reading frame (ORF) of UL38 gene were cloned, for the first time, into pET-32a (+) expression vector to obtain abundant recombinant proteins in E. coli. Moreover, their antigenic properties were characterized by western blot analysis and ELISA. Subsequently, two polyclonal antibodies were raised against the purified recombinant proteins in rabbits, and the titer and specificity of the polyclonal antibodies were characterized further by ELISA and immunofluorescent assays.

\section{Results}

\section{Expression and purification of recombinant DEV VP19c} and VP19c(N)

The cloning strategy for constructing the recombinant plasmids is shown in Figure 1. The N-terminally Histagged rVP19c and rVP19c(N) were produced in E. coli strain BL21 (DE3) with molecular weight of about 66 and $46 \mathrm{kDa}$ (Figure 2). The optimal temperatures for rVP19c and rVP19c(N) expression were $30^{\circ} \mathrm{C}$ and $37^{\circ} \mathrm{C}$ (Figure 3) respectively, and optimal induction times for them were both about 4 h (Figure 4), while concentrations of IPTG (data not shown) had a little influence on their expression. With the analysis of software BandScan 5.0, the induced $\mathrm{rVP} 19 \mathrm{c}$ and $\mathrm{rVP} 19 \mathrm{c}(\mathrm{N})$ reached approximately $40 \%$ and $70 \%$ in the total bacteria protein of each $1 \mathrm{ml}$ culture, respectively.

The rVP19c and rVP19c(N) (Figure 5) were successfully expressed as inclusion bodies in E. coli and isolated roughly. The final yields of denatured soluble inclusion bodies were estimated to be approximately $100 \mathrm{mg} / \mathrm{L}$ $(\mathrm{rVP} 19 \mathrm{c})$ and $150 \mathrm{mg} / \mathrm{L}(\mathrm{rVP} 19 \mathrm{c}(\mathrm{N}))$ of initial bacterial culture. Then the proteins were purified by IMAC under denaturing conditions to reach the level of homogeneity (Figure 5).

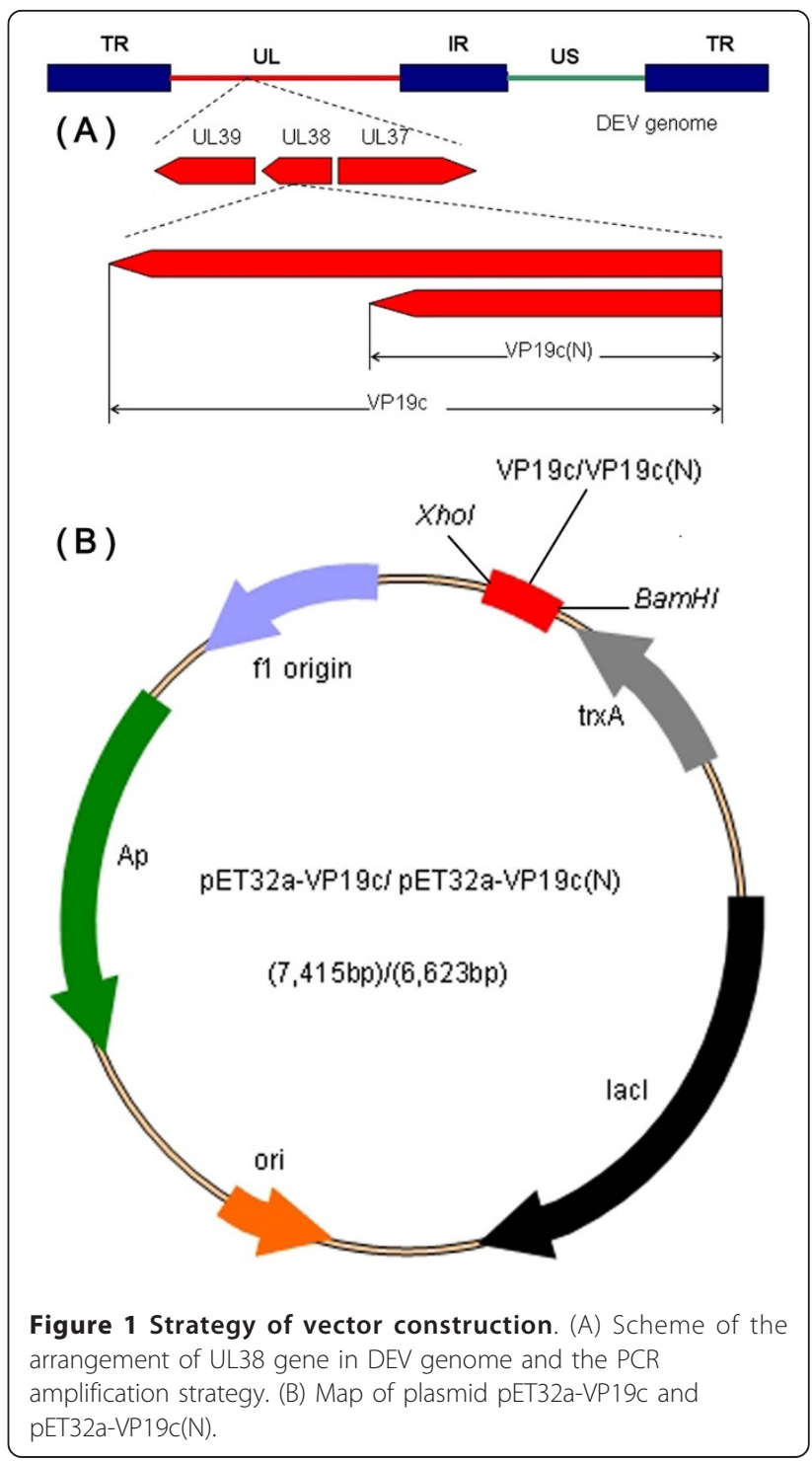

Antigenicities analysis of rVP19c and rVP19c(N)

As shown in Figure 6, polyclonal antibody from rabbit immunized against purified DEV reacted with $\mathrm{rVP19c}$ and $\mathrm{rVP} 19 \mathrm{c}(\mathrm{N})$. The results showed a similar immunedetection pattern as the native VP19c protein presented in the virus and the $\mathrm{VP} 19 \mathrm{c}(\mathrm{N})$ was involved in antigenic recognition of lineal-epitopes recognized by $\mathrm{PAb}$ under denaturing conditions. In ELISA assay, the positive serum was able to recognize the $\operatorname{rVP} 19 \mathrm{c}(\mathrm{N})$ protein at a similar level as rVP19c protein(Figure 7), which indicated that the linear epitopes within $\mathrm{VP} 19 \mathrm{c}(\mathrm{N})$ recognized by positive serum were the same in the VP19c protein.

\section{Characterization of the polyclonal antibodies against rVP19c and rVP19c(N) proteins}

The antibodies against $\mathrm{rVP} 19 \mathrm{c}$ and $\mathrm{rVP} 19 \mathrm{c}(\mathrm{N})$ proteins at different dilutions were reacted with fusion proteins, 


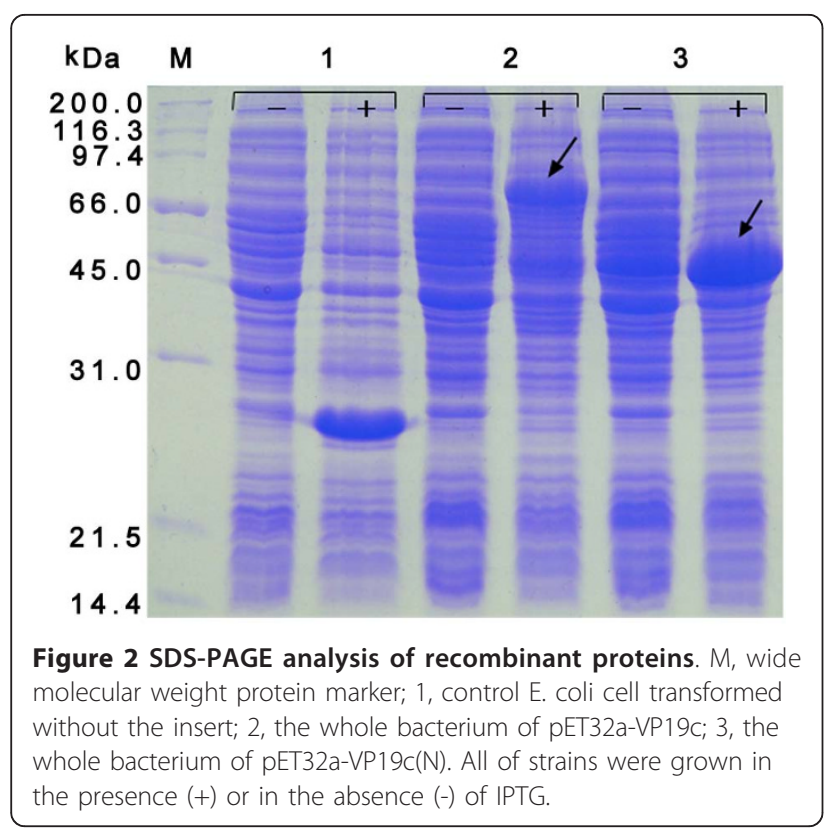

pre-immunized rabbit serum served as the negative control. The two antibodies titer were found to be approximately 1:12 800. At the same time, negative control did not result in a detectable signal (data not shown).

As shown in Figure 8G, anti-rVP19c serum was able to detect the VP19c protein in DEV infected cells and the VP19c protein targeted to the nucleus as distinct punctate speckles. In contrast, there was no staining in mock infected cells (Figure 8A) or DEV infected cells detected with the preimmune serum (Figure 8D). Similarly, the antibody against $\operatorname{rVP} 19 \mathrm{c}(\mathrm{N})$ was able to recognize the VP19c protein in the cells infected with DEV (data not shown).

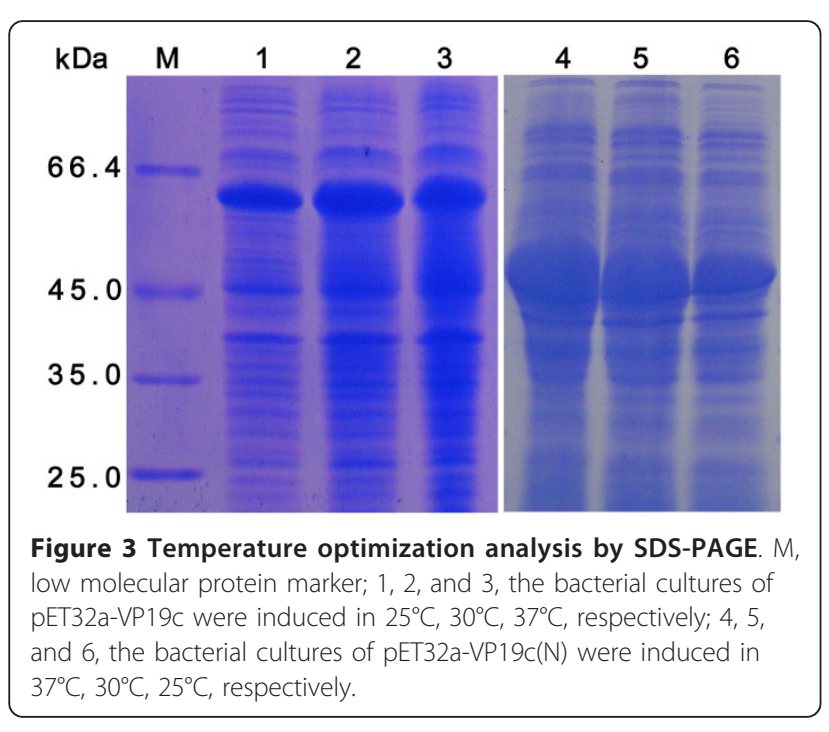

\section{Discussion}

Currently, morphological features $[3,10]$ and complete genome sequence [11] of DEV have been defined, but studies on proteins of DEV virion, especially structural and functional characteristics of viral structural proteins, have been very few. Generally, the structural viral proteins have various functions during the replicative cycle, which might be closely related to their structure [12]. Therefore, the understanding of the function of each structural protein depends on the study at a molecular level.

Computational predictions of the VP19c amino acid sequence suggested that it did not require any posttranslational modifications and lacked transmembrane regions and signal peptides, so it is more suitable for prokaryotic expression. And predictions presented the $\mathrm{N}$-terminus of VP19c protein may contain most antigenic linear-epitopes [9].

To obtain high-level expression, several expression conditions, such as induction time, induction temperature, and IPTG concentration were optimized. It could be seen that temperature of induction is critical. After induction conditions optimized, the expected high-level expression result was obtained.

Western blot confirmed that the expressed recombinant proteins were specific to DEV and had good antigenicity. These results strongly suggested that the purified rVP19c protein seemed to be structurally and antigenically very similar to native VP19c protein and the antigenicity of VP19c was also mainly determined by linear antigenic determinant of it. Inclusion bodies (IBs) are denatured proteins and lack conformational epitopes. Thus it can be seen that though the IBs are inactivated form of protein, they are sufficient for animal immunity and harvest of specific sera [13]. Moreover, the $\mathrm{rVP19c}(\mathrm{N})$ was deleted $\mathrm{C}$-terminus, but still remained good antigenicity. The results of ELISA assays showed that the antibody in the duck sera raised against the complete VP19c protein were primarily against the $\mathrm{N}$-terminal region of the VP19c protein, which indicated that the N-terminal portion of the VP19c protein may harbor most of the linear epitopes. Furthermore, antirVP19c serum was able to detect the VP19c protein in DEV infected cells, which indicated that this specific polyclonal antibody provide a good tool for further studying structural and functional characterization of DEV VP19c.

Currently, little is known about DEV VP19c function or regulation of expression, as well as other features. Homology analysis with other herpesviruses suggested that the DEV VP19c protein could be a crucial capsid protein [14]. Conservation of the protein suggests that it may play a role in the viral life cycle. Because of the localization of VP19c to viral factories, we investigated 


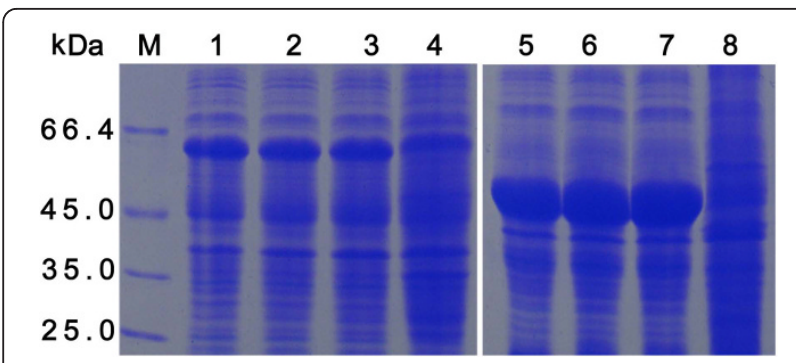

Figure 4 Time optimization analysis by SDS-PAGE. M, IOW molecular protein marker; 1, 2, 3, and 4, the bacterial cultures of pET32a-VP19c were induced for 3 h, 4 h, 5 h, overnight (16 h), respectively; $5,6,7$, and 8 , the bacterial cultures of pET32a-VP19c(N) were induced for 3 h, 4 h, 5 h, overnight (16 h), respectively.

the possibility that this protein might be incorporated into DEV virions.

\section{Conclusions}

To our knowledge, this was the first report on basic properties of DEV VP19c protein. In the present study, we obtained a high-level expression of the recombinant VP19c protein as well as high titers of rabbit polyclonal antibody against to VP19c protein. The anti-rVP19c serum was able to detect the VP19c protein in DEV infected cells and the VP19c protein targeted to the nucleus as distinct punctate speckles. This specific polyclonal antibody provides a good tool for further studying structural and functional characterization of DEV VP19c.

\section{Methods}

\section{Construction of plasmid}

The viral DNA was extracted from partially purified DEV and used as template for polymerase chain

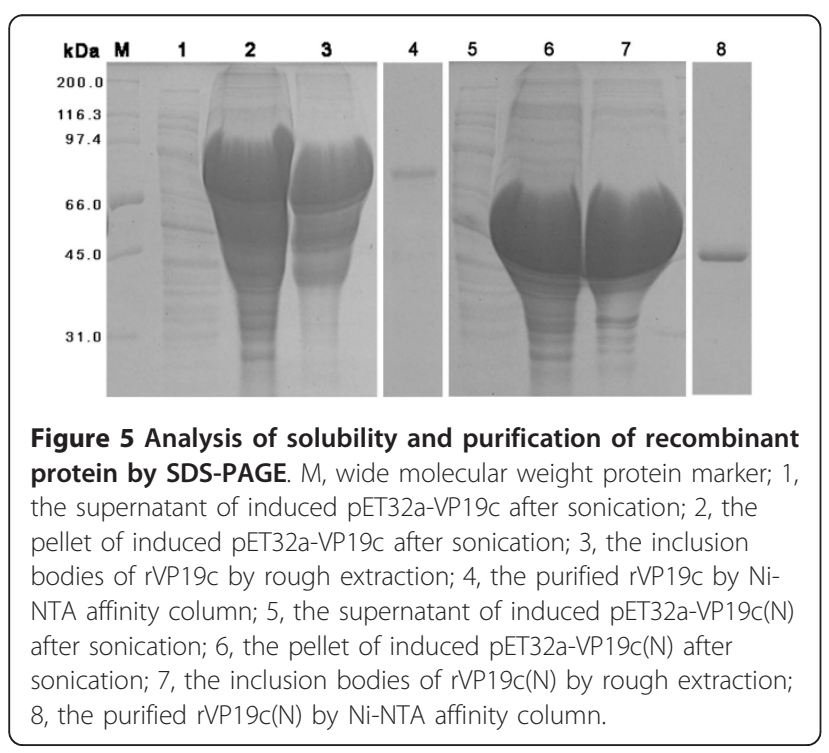

reaction (PCR) [15]. A fragment (1515 bp) containing the complete ORF of DEV UL38 gene (1398 bp) (Genbank accession no. EU071041) was amplified using PCR with the following primers: the upstream primer (P1) 5'GGATCCACGATGAAAGTACCAAATG-3' containing the BamHI site and the downstream primer (P2) 5'CTCGAGAGCCAGATACGAC AAGAAG-3' containing the Xhol site. The PCR parameters were $10 \mathrm{~min}$ at $95^{\circ} \mathrm{C}$ and 30 cycles of $1 \mathrm{~min}$ at $94^{\circ} \mathrm{C}, 1 \mathrm{~min}$ at $58.5^{\circ} \mathrm{C}, 1 \mathrm{~min}$ at $72^{\circ} \mathrm{C}$, and a final extension time of $10 \mathrm{~min}$ at $72^{\circ} \mathrm{C}$. A fragment (723 bp) containing the partial ORF (711 bp) encoding the N-terminal of VP19c $(\mathrm{VP} 19 \mathrm{c}(\mathrm{N}))$ protein was amplified with the following primers: the upstream primer (P1) 5'-GGATCCACGATGAAAGTACCAAA TG-3' containing the BamHI siteand the downstream primer (P3) 5' -CTCGAGGTGTACGTGAC ATCTAACCA TAG-3' containing the XhoI site. The PCR assay and programme were carried out following the protocol described above.

The PCR products and plasmid pET-32a(+) (Qiagen $\mathrm{GmbH}$, Hilden, Germany) were both digested with BamH I and Xho I, and then ligated with T4 DNA ligase to yield the constructs. The constructs were transformed into E.coli, and the selected bacterial transformants were verified by colony PCR, restriction enzyme analysis and sequencing.

\section{Expression}

The positive individual clone was cultured in $5 \mathrm{~mL}$ Luria bertani (LB) medium containing $100 \mathrm{ug} / \mathrm{mL}$ amp and then induced at $37^{\circ} \mathrm{C}$ by adding isopropyl- $\beta$-D-thiogalactoside (IPTG) at a final concentration of $1 \mathrm{mM}$ for $4 \mathrm{~h}$. For IPTG dose optimization, the bacterial culture was induced with different concentrations of IPTG [0.2, 0.3, $0.4,0.5,0.6,0.7,0.8,0.9,1.0(\mathrm{mM})]$ and allowed to grow for $4 \mathrm{~h}$ at $37^{\circ} \mathrm{C}$. For temperature optimization, the bacterial culture was induced with IPTG [1.0 (mM)] and allowed to grow for $4 \mathrm{~h}$ at three different temperatures $(25,30$ and $37^{\circ} \mathrm{C}$ ). For time optimization, the bacterial culture was induced with IPTG $[1.0(\mathrm{mM})]$ and allowed to grow for $3 \mathrm{~h}, 4 \mathrm{~h}, 5 \mathrm{~h}$ and overnight $(\sim 16 \mathrm{~h})$ at $37^{\circ} \mathrm{C}$. Total cell proteins from each optimization experiment were analyzed by sodium dodecyl sulfate-polyacrylamide gel electrophoresis (SDS-PAGE). Then, small-scale expression was done by optimized conditions as described above to prepare for purification [16]. The protein amount was determined with reference to standard bovine serum albumin (BSA) in the Bradford assay [17].

\section{Purification}

$500 \mathrm{ml}$ induced bacterial culture was harvested after $4 \mathrm{~h}$, centrifuged at $6000 \times \mathrm{g}$ for $10 \mathrm{~min}$ and the cell pellet was suspended in $20 \mathrm{mM}$ Tris buffer $(\mathrm{pH}=8.0)$. The cells were later lysed by using lysozyme $(0.1 \mathrm{mg} / \mathrm{mL})$ at 


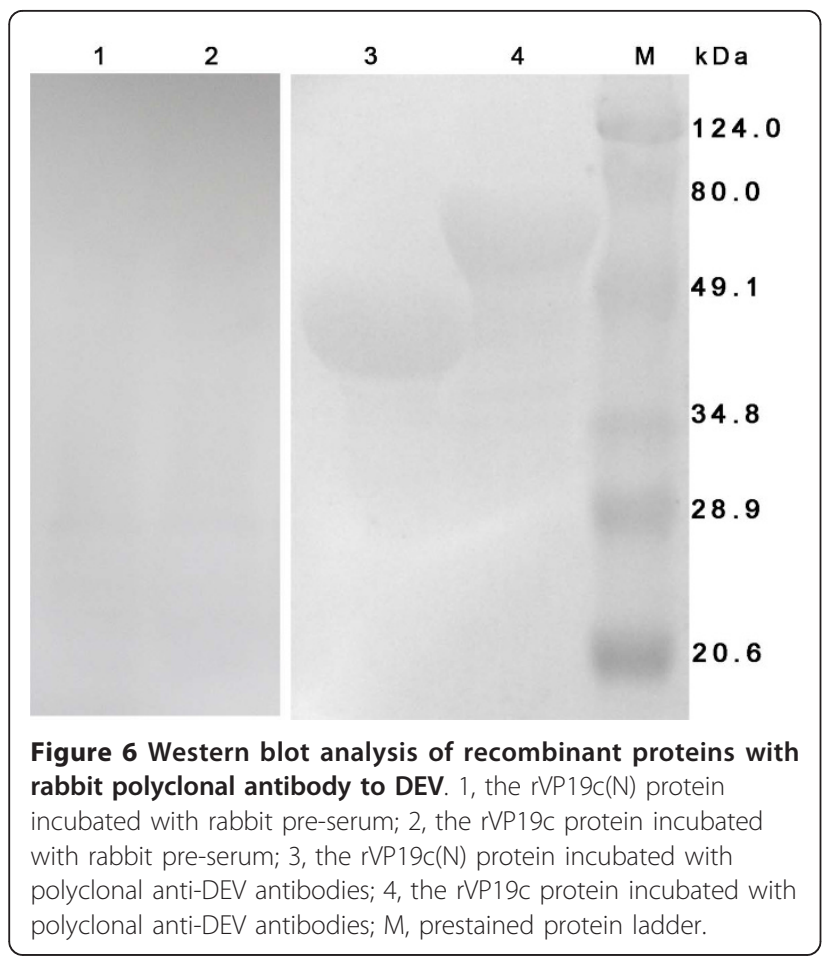

$4^{\circ} \mathrm{C}$ for $1 \mathrm{~h}$ and sonicated on ice for $5 \mathrm{~min}$ at an amplitude of $30 \%$ with a 30 s pulse frequency. The lysate was centrifuged at $10,000 \times \mathrm{g}$ for $20 \mathrm{~min}$ at $4^{\circ} \mathrm{C}$ and the supernatant was collected as soluble fraction. The resulting pellet was washed twice with $10 \mathrm{~mL} 2 \mathrm{M}$ urea containing $50 \mathrm{mM}$ Tris buffer $(\mathrm{pH}=8.0), 1 \mathrm{mM}$ EDTA, $150 \mathrm{mM} \mathrm{NaCl}$ and $0.1 \%$ Triton X-100.

The suspension was centrifuged at $10,000 \times \mathrm{g}$ for 20 $\min$ at $4^{\circ} \mathrm{C}$ and then the resulting subsidence was resuspended in regeneration buffer containing $6 \mathrm{M}$ urea, 0.5 $\mathrm{M} \mathrm{NaCl}, 20 \mathrm{mM}$ Tris- $\mathrm{HCl}(\mathrm{pH}$ 7.9) and incubated at room temperature for $30 \mathrm{~min}$. The incubated mixtures were then centrifuged at $10,000 \times \mathrm{g}$ for $20 \mathrm{~min}$, and the supernatant was submitted to further purification. The supernatant was then poured on to a purification column and allowed to bind for $1 \mathrm{~h}$ with gentle shaking. The recombinant His-tagged proteins were purified from the supernatant obtained above by immobilized metal affinity chromatography (IMAC) on Ni-NTA affinity resin (Bio-Rad) following the conventional protocol [18]. Finally, the proteins were collected and analyzed by SDS-PAGE to assess the level of homogeneity.

\section{Western blot}

The recombinant proteins were electrophoresed with SDS-PAGE using $12 \%$ polyacrylamide gel and then electroblotted onto polyvinylidene fluoride (PVDF) membrane. The PVDF membrane was blocked with 3\% bovine serum albumin (BSA) in Tris-Buffered Saline Tween-20 (TBST) Buffer containing $20 \mathrm{mM}$ Tris$\mathrm{HCl}, 150 \mathrm{mM} \mathrm{NaCl}$ and $0.05 \%$ Tween 20 overnight at $4^{\circ}$ C. The membrane was washed three times with TBST and incubated for $1 \mathrm{~h}$ at $37^{\circ} \mathrm{C}$ with rabbit anti-DEV polyclonal antibody and rabbit pre-serum at 1:100 of

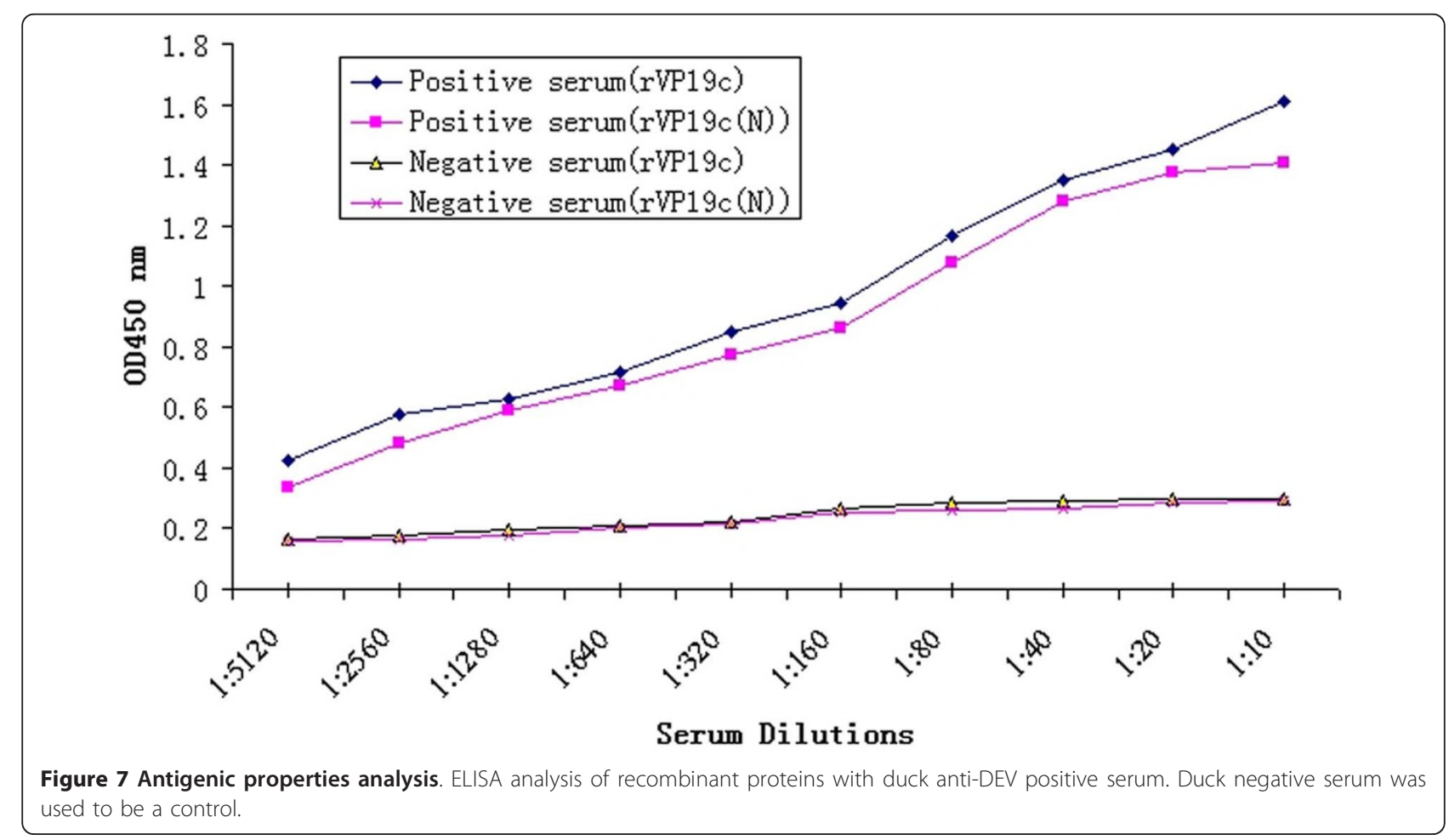




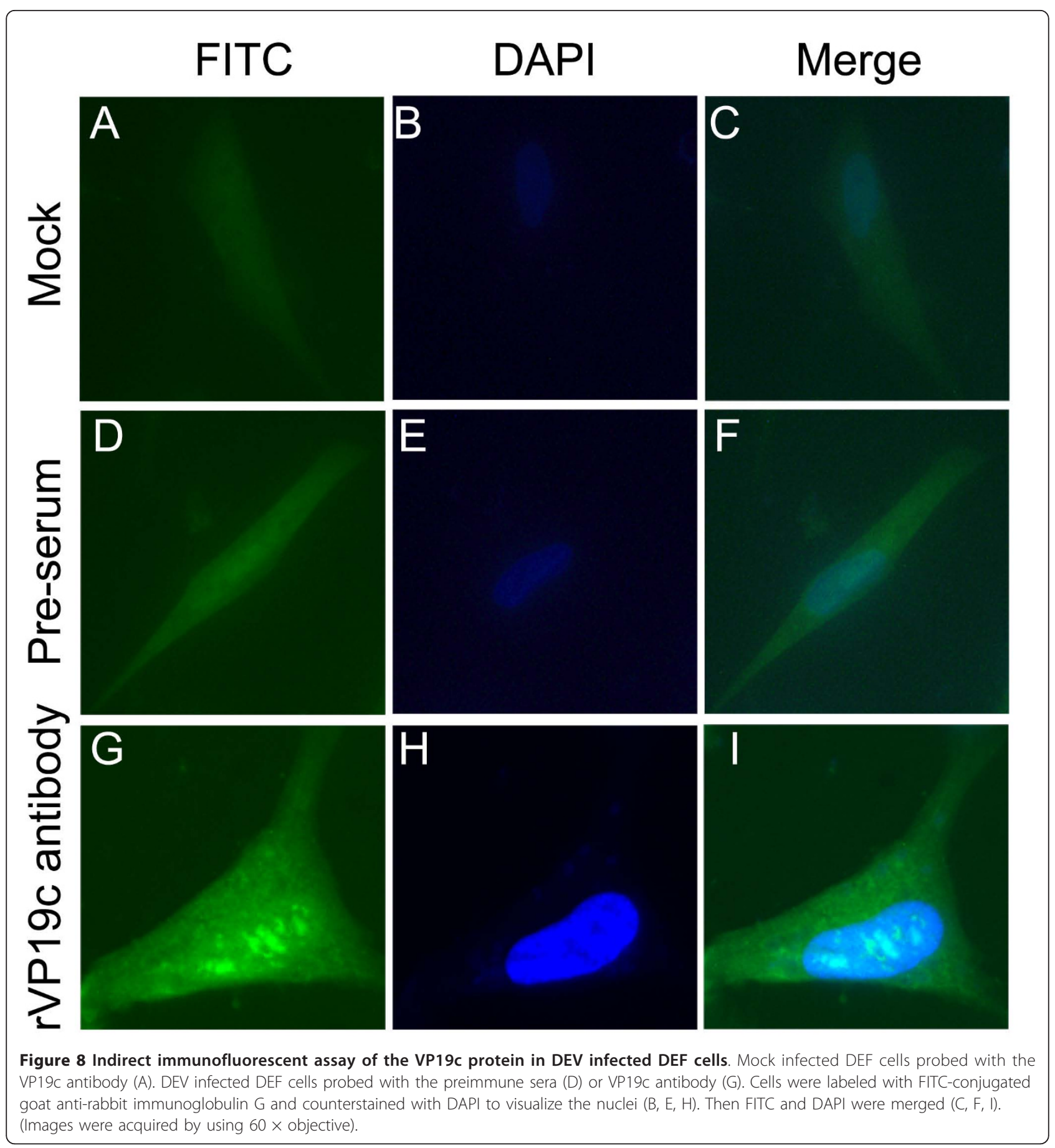

dilution in TBST buffer containing 0.5\% BSA. After washing, the membrane was incubated for $1 \mathrm{~h}$ at $37^{\circ} \mathrm{C}$ with anti-rabbit-HRPO conjugated IgG(GE Healthcare Limited, Buckinghamshire, United Kingdom) at 1:5000 of dilution in TBST buffer containing 0.5\% BSA. Finally, the membrane was washed with TBST and placed in diamino benzidine (DAB) solution as a chromogen to visualize the binding.

\section{Indirect ELISA}

Flat bottomed 96 well plate (Corning, Corning Costar Corp., MA, USA) was coated overnight at $4^{\circ} \mathrm{C}$ with the recombinant proteins at $7 \mathrm{ug} / \mathrm{ml}$ in carbonate bicarbonate buffer, $\mathrm{pH}$ 9.6. After blocking with 1\% BSA in PBS, the wells were washed with PBS containing $0.05 \%(\mathrm{v} / \mathrm{v})$ Tween-20 (PBST) and later incubated at $37^{\circ} \mathrm{C}$ for $1 \mathrm{~h}$ with various dilutions (1:5120-1:10) of duck anti-DEV 
strain Chv positive serum and negative serum. After washing with PBST, the plates were incubated at $37^{\circ} \mathrm{C}$ for $1 \mathrm{~h}$ with anti-duck-HRPO conjugated $\operatorname{IgG}(\mathrm{GE}$ Healthcare Limited, Buckinghamshire, United Kingdom). Finally, the plate was washed and the peroxidase reaction was visualized by using tetrame-thylbenzidine (TMB) (Sigma) as substrate after incubation for $10 \mathrm{~min}$ at room temperature. The reaction was stopped by adding $2 \mathrm{M} \mathrm{H}_{2} \mathrm{SO}_{4}$ and absorbance was read at $450 \mathrm{~nm}$ by a microplate autoreader (Bio-Rad).

\section{Production of polyclonal antibody}

Preimmune serum was collected prior to immunization. New Zealand white rabbits were immunized firstly intradermally with a mixture of $1 \mathrm{mg}$ purified recombinant $\mathrm{rVP19c}$ or $\operatorname{rVP} 19 \mathrm{c}(\mathrm{N})$ mixed with an equal volume of complete Freund's adjuvant (Sigma). Two weeks later, the rabbits were boosted twice subcutaneously with the same amount of recombinant proteins mixed with an equal volume of incomplete Freund's adjuvant at a oneweek interval. Two weeks after the last immunization, the two antiserums were harvested from the carotid artery. Then the polyclonal antibody was purified by protein A affinity IgG purification kit according the user's guide. The titer of the specific antibodies was determined by ELISA.

\section{Indirect immunofluorescent assay}

For immunofluorescence assays, monolayers of duck embryo fibroblast (DEF) cells were infected (MOI 5) with the DEV strain Chv and then incubated for $30 \mathrm{~h}$ at $37^{\circ} \mathrm{C}$. Cells were fixed with $4 \%$ paraformaldehyde for 30 min, washed with PBS and permeabilized with $0.5 \%$ Triton X-100 for $10 \mathrm{~min}$. After washing, the cells were blocked with PBS containing 5\% BSA for $1.5 \mathrm{~h}$ at $37^{\circ} \mathrm{C}$. Subsequently, the cells were incubated with rVP19c-specific polyclonal antibody diluted in PBS containing $0.5 \%$ BSA for $1 \mathrm{~h}$ at $37^{\circ} \mathrm{C}$. Finally, fluorescein isothiocyanate (FITC)-conjugated goat anti-rabbit immunoglobulin G (Sigma) was added at a dilution of 1:200 and incubated at $4^{\circ} \mathrm{C}$ for $16 \mathrm{~h}$. After each incubation step, the cells were washed extensively with PBS. The cell nuclei were visualized by DAPI counterstaining [19-21]. The images captured with fluorescence microscopy (Nikon, Japan).

\section{Acknowledgements}

The research was supported by grants from the Changjiang Scholars and Innovative Research Team in University (PCSIRT0848), the earmarked fund for Modern Agroindustry Technology Research System (nycytx-45-12).

\section{Author details}

${ }^{1}$ Avian Diseases Research Center, College of Veterinary Medicine of Sichuan Agricultural University,Ya'an, Sichuan, PR China. ${ }^{2}$ Key Laboratory of Animal Diseases and Human Health of Sichuan Province, Ya'an, Sichuan, PR China. ${ }^{3}$ Epizootic Diseases Institute of Sichuan Agricultural University, Ya'an, Sichuan, PR China.

\section{Authors' contributions}

JX and SCZ carried out most of the experiments and drafted the manuscript ACC and MSW have critically revised the manuscript and the experimental design. HC, CJS, DKZ, RYJ, QHL, ZLC and XYC helped in experiments. All authors have read and approved the final manuscript.

\section{Competing interests}

The authors declare that they have no competing interests.

Received: 22 November 2010 Accepted: 24 February 2011 Published: 24 February 2011

\section{References}

1. Fadly AM, Glisson JR, McDougald LR, Nolan Lk, Swayne DE: Duck Virus Enteritis. In Diseases of Poultry. 12 edition. Edited by: Saif YM. American, Wiley-Blackwell; 2008:384-393.

2. Spieker JO, Yuill TM, Burgess EC: Virulence of six strains of duck plague virus in eight waterfowl species. J Wildlife Dis 1996, 32:453-460.

3. Guo YF, Cheng AC, Wang MS, Zhou Y: Purification of anatid herpesvirus 1 particles by tangential-flow ultrafiltration and sucrose gradient ultracentrifugation. J Virol Methods 2009, 161:1-6.

4. Bowman BR, Baker ML, Rixon FJ, Chiu W, Quiocho FA: Structure of the herpesvirus major capsid protein. The EMBO J 2003, 22:757-765.

5. Okoye ME, Sexton GL, Huang E, McCaffery JM, Desai P: Functional analysis of the triplex proteins (VP19C and VP23) of herpes simplex virus type 1. J Virol 2006, 80:929-940.

6. Flanagan WM, Papavassilion AG, Rice MK, Hecht LB, Silverstein S, Wagner EK: Analysis of the herpes simplex virus type 1 promoter controlling the expression of UL38, a true late gene involved in capsid assembly. J Virol 1991, 65:769-786.

7. Wirth UV, Kristin G, Monika E, Martin S: Spatial and temporal distribution of bovine herpesvirus 1 transcripts. J Virol 1989, 63:4882-4889.

8. Braun A, Kaliman A, Boldogkoi Z, Aszodi A, Fodor I: Sequence and expression analyses of the UL37 and UL38 genes of Aujeszky's disease virus. Acta Vet Hungarica 2000, 48:125-136.

9. Xiang J, Cheng AC, Wang MS, Chang H, Chen WP: Molecular cloning and sequence analysis of the duck enteritis virus nucleocapsid gene(UL38). IEEE BMEl'09 2nd Inter Conf on 2009, 4:1874-1880.

10. Guo YF, Shen CJ, Cheng AC, Wang MS, Zhang N, Chen S, Zhou Y: Anatid herpesvirus $1 \mathrm{CH}$ virulent strain induces syncytium and apoptosisin duck embryo fibroblast cultures. Vet Microbiol 2009, 138:258-265.

11. Li YF, Huang B, Ma XL, Wu J, Li F, Ai W, Song MX, Yang HC: Molecular characterization of the genome of duck enteritis virus. Virology 2009, 391:151-161.

12. Royuela E, Fauquier AS: Molecular cloning, expression and first antigenic characterization of human astrovirus VP26 structural protein and a Cterminal deleted form. Comp Immunol Microbiol Infect Dis 2010, 33:1-14.

13. Ventura S, Villaverde A: Protein quality in bacterial inclusion bodies. Trends in Biotechnology 2006, 24:179-185.

14. Xiang J, Cheng AC, Wang MS, Chang H, Zhang SC: Analysis of synonymous codon usage in the capsid gene UL38 of duck enteritis virus. 2010, IEEE ICBBE'10 4rd Inter Conf on.

15. Guo YF, Cheng AC, Wang MS, Shen CJ, Jia RY, Chen S, Zhang N: Development of TaqMan ${ }^{\circledR}$ MGB fluorescent real-time PCR assay for the detection of anatid herpesvirus 1. Virology Journal 2009, 6:71.

16. Zhang SC, Ma GP, Xiang J, Cheng AC, Wang MS, Zhu DK, Jia RY, Luo QH, Chen $\mathrm{ZL}$, Chen XY: Expressing gK gene of duck enteritis virus guided by bioinformatics and its applied prospect in diagnosis. Virology Journal 2010, 7:168.

17. Bradford MM: A rapid and sensitive method for the quantitation of microgram quantities of protein utilizing the principle of protein-dye binding. Anal. Biochem 1976, 72:248-254.

18. Lu LT, Cheng AC, Wang MS, Jiang JF, Zhu DK, Jia RY, Luo QH, Liu F, Chen ZL, Chen XY, Yang JL: Polyclonal antibody against the DPV UL46M protein can be a diagnostic candidate. Virology Journal 2010, 7:83.

19. Xie W, Cheng AC, Wang MS, Chang H, Zhu DK, Luo QH, Jia RY, Chen XY: Expression and characterization of the UL31 protein from duck enteritis virus. Virology Journal 2009, 6:19.

20. Shen CJ, Guo YF, Cheng AC, Wang MS, Zhou Y, Lin D, Xin HY, Zhang N: Characterization of subcellular localization of duck enteritis virus UL51 protein. Virology Journal 2009, 6:92. 
21. Chang H, Cheng AC, Wang MS, Zhu DK, Jia RY, Liu F, Chen ZL, Luo QH, Chen XY, Zhou Y: Cloning, expression and characterization of gE protein of Duck plague virus. Virology Journal 2010, 7:120.

doi:10.1186/1743-422X-8-82

Cite this article as: Xiang et al:: Expression and characterization of recombinant VP19c protein and N-terminal from duck enteritis virus. Virology Journal 2011 8:82.

Submit your next manuscript to BioMed Central and take full advantage of:

- Convenient online submission

- Thorough peer review

- No space constraints or color figure charges

- Immediate publication on acceptance

- Inclusion in PubMed, CAS, Scopus and Google Scholar

- Research which is freely available for redistribution

Submit your manuscript at www.biomedcentral.com/submit 